\title{
Selected aspects of the nanofluids utilization as the heat transfer carriers
}

\author{
Aleksandra Roszko $^{1 *}$, and Elzbieta Fornalik-Wajs ${ }^{1}$ \\ ${ }^{1}$ AGH University of Science and Technology, Faculty of Energy and Fuels Department of \\ Fundamental Research in Energy Engineering, al. Mickiewicza 30, 30-059 Kraków, Poland
}

\begin{abstract}
Since many years the nanofluids rise an interest of the researchers in various areas from cosmetology through medicine to technics. In each area potential of the nanofluids depends on various properties, which may be utilized. Considering the technical applications, very important one is related to the energy systems. Present paper discusses the heat transfer enhancement as the main aspect of nanofluid potential in this area. It presents also new research direction regarding the magnetic field influence on a convection of the nanofluids. The experimental analysis gives promising results especially in the context of space applications.
\end{abstract}

\section{Introduction}

Sometimes, due to increasing energy consumption the problems with assurance of energy delivery appear, especially during the summer, resulting in the restrictions of electricity usage, e.g. for air conditioning or escalators in shopping malls. Therefore, the attention was directed towards the natural and renewable energy sources as the solar, wind or geothermal ones. Moreover, the idea of old systems improvement also drives the research activities. Any method, which will result in higher efficiency is welcomed. One of such methods considers application of new kind of fluid - nanofluid - classical fluid with addition of solid particles of nanosize. Nanofluids are subject of numerous papers (as presented in Fig. 1) and their number is still increasing. Popularity is connected with their properties, which, according to many studies [1-3], are different in comparison with the base fluid ones. At the beginning, it was only the concept, which couldn't be verified due to the technology limitations. However in early 90's of XX century the first fluid with nanoparticles was prepared. Very first studies of nanofluid properties [4] were promising, especially with reference to the thermal conductivity (some of them are presented in Table 1). Many researchers studied this topic, however it turned out that there were and are a lot of challenges, since the reported results were ambiguous. Still, there are many open questions concerning nanofluid behaviour, e.g. mechanism responsible for thermal properties enhancement, particles agglomeration or sedimentation problems $[5,6]$.

Nonetheless, the topic of nanofluid application is intensively studied (see in Fig. 1) and the areas of nanofluid application are diverse. The most difficult issue in regard with practical nanofluid application is the particles tendency to agglomeration. Forms of the agglomerates

\footnotetext{
* Corresponding author: roszko@agh.edu.pl
} 
can vary in their amount, size and configuration, and they can change with time. Therefore it is difficult to predict and to control them. It is known, that agglomeration of the nanoparticles is present and has an influence on the nanofluid properties, changing its performance. However, it was proved that nanofluids prepared by ultrasonic dispersion were characterized by improved stability. Another way to stabilize nanoparticles dispersion in the fluid can be addition of the surfactants, but the fluid $\mathrm{pH}$ is influenced causing limitation of its applicability.

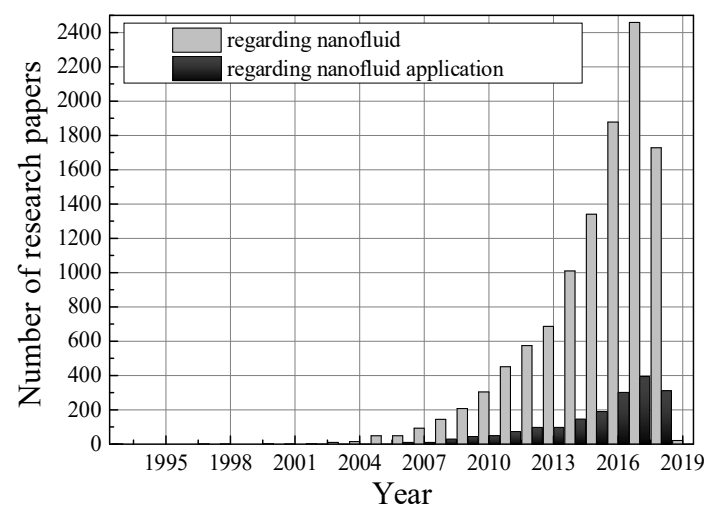

Fig. 1. Number of research papers concerning nanofluids and their application (on the basis of Web of Science, September of 2018 year)

This paper describes the results regarding possible applications of the nanofluids in the solar, nuclear reactors and space systems. At the end the complimentary studies of the magnetic field influence on the nanofluid flow and heat transfer are mentioned. The results are optimistic in the context of space applications, but not limited to them.

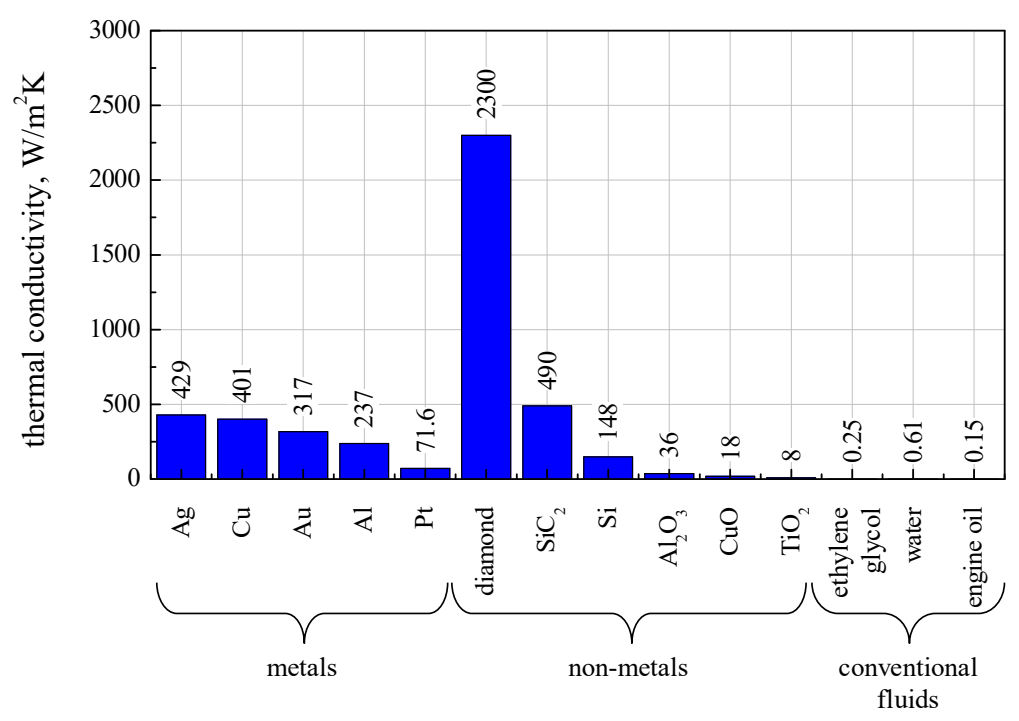

Fig. 2. Thermal conductivity values for various substances (reference tempertature was $298 \mathrm{~K}$ ) [25] 
Table 1. Thermal conductivity enhancement reported by various researchers

\begin{tabular}{|c|c|c|c|c|c|}
\hline Source & Base fluid & $\begin{array}{l}\text { Particles } \\
\text { material }\end{array}$ & $\begin{array}{ll}\text { Particles } & \text { shape } \\
\text { and size } & \end{array}$ & $\begin{array}{l}\text { Particles volume } \\
\text { fraction }\end{array}$ & $\begin{array}{l}\text { Thermal } \\
\text { conductivity } \\
\text { improvement }\end{array}$ \\
\hline $\begin{array}{l}\text { Choi and } \\
\text { Eastman [4] }\end{array}$ & water & $\mathrm{Cu}$ & $\begin{array}{l}\text { sphere, } \\
\text { size unknown }\end{array}$ & $5-20$ vol. $\%$ & $10-250 \%$ \\
\hline \multirow{3}{*}{$\begin{array}{l}\text { Chon et al. } \\
\text { [2] } \\
\text { Choi [16] }\end{array}$} & water & $\mathrm{Al}_{2} \mathrm{O}_{3}$ & sphere, $11 \mathrm{~nm}$ & 1 vol.\% & $22 \%$ \\
\hline & water & $\mathrm{Al}_{2} \mathrm{O}_{3}$ & sphere, $47 \mathrm{~nm}$ & 1 vol. $\%$ & $7 \%$ \\
\hline & water & $\mathrm{Al}_{2} \mathrm{O}_{3}$ & sphere, $150 \mathrm{~nm}$ & 1 vol. $\%$ & $2 \%$ \\
\hline \multirow[t]{3}{*}{$\begin{array}{l}\text { Eastman et } \\
\text { al. [1] }\end{array}$} & $\begin{array}{l}\text { ethylene } \\
\text { glycol }\end{array}$ & $\mathrm{Cu}$ & sphere, $10 \mathrm{~nm}$ & $0.1-0.25$ vol. $\%$ & $2-40 \%$ \\
\hline & $\begin{array}{l}\text { ethylene } \\
\text { glycol }\end{array}$ & $\mathrm{CuO}$ & sphere, $35 \mathrm{~nm}$ & $1-4$ vol. $\%$ & $5-22 \%$ \\
\hline & $\begin{array}{l}\text { ethylene } \\
\text { glycol }\end{array}$ & $\mathrm{Al}_{2} \mathrm{O}_{3}$ & sphere, unknown & $1-3$ vol. $\%$ & $2-14 \%$ \\
\hline \multirow{2}{*}{$\begin{array}{l}\text { Das et al., } \\
\text { Xie et al. } \\
{[16,17]}\end{array}$} & $\begin{array}{l}\text { distilled } \\
\text { water }\end{array}$ & $\mathrm{SiC}$ & $\begin{array}{l}\text { sphere, } \\
26 \mathrm{~nm}\end{array}$ & $1.5-4.2$ vol. $\%$ & $5-15 \%$ \\
\hline & $\begin{array}{l}\text { distilled } \\
\text { water }\end{array}$ & $\mathrm{SiC}$ & sphere, $600 \mathrm{~nm}$ & $1-4$ vol. $\%$ & $6.5-22 \%$ \\
\hline $\begin{array}{l}\text { Xuan and } \\
\mathrm{Li} \text {, Das et } \\
\text { al. }[17,18]\end{array}$ & $\begin{array}{l}\text { transforme } \\
\text { r oil }\end{array}$ & $\mathrm{Cu}$ & sphere, $100 \mathrm{~nm}$ & $2.2-7.6$ vol. $\%$ & $12-42 \%$ \\
\hline \multirow{2}{*}{$\begin{array}{l}\text { Das et al. } \\
{[19]}\end{array}$} & water & $\mathrm{Al}_{2} \mathrm{O}_{3}$ & sphere, $38.4 \mathrm{~nm}$ & $1-4$ vol. $\%$ & $2-8 \%$ \\
\hline & water & $\mathrm{CuO}$ & sphere, $23.6 \mathrm{~nm}$ & $1-4$ vol. $\%$ & $7-14 \%$ \\
\hline \multirow{3}{*}{$\begin{array}{l}\mathrm{Xie} \text { et al. } \\
{[20]}\end{array}$} & decene & CNT & sphere, $50 \mathrm{~nm}$ & $0.25-1$ vol.\% & $5-20 \%$ \\
\hline & $\begin{array}{l}\text { distilled } \\
\text { water }\end{array}$ & CNT & sphere, $50 \mathrm{~nm}$ & $0.4-1$ vol. $\%$ & $3-7 \%$ \\
\hline & $\begin{array}{l}\text { ethylene } \\
\text { glycol }\end{array}$ & CNT & sphere, $50 \mathrm{~nm}$ & $0.25-1$ vol. $\%$ & $3-12 \%$ \\
\hline $\begin{array}{l}\text { Garg et al. } \\
\text { [21] }\end{array}$ & $\begin{array}{l}\text { ethylene } \\
\text { glycol }\end{array}$ & $\mathrm{CuO}$ & sphere, $200 \mathrm{~nm}$ & $0.4-2$ vol. $\%$ & $2-12.5 \%$ \\
\hline $\begin{array}{l}\text { Chen and } \\
\text { Wang [22] }\end{array}$ & water & $\mathrm{TiO}_{2}$ & $\begin{array}{l}\text { tube shape } \\
10 \mathrm{~nm} \times 100 \mathrm{~nm}\end{array}$ & $0.25-6$ vol. $\%$ & $2.5-5.5 \%$ \\
\hline \multirow[t]{2}{*}{$\begin{array}{l}\text { Patel et al. } \\
\text { [23] }\end{array}$} & water & $\begin{array}{l}\mathrm{Au} \\
\text { thiolate }\end{array}$ & sphere, 3-4 nm & $\begin{array}{l}0.005- \\
0.011 \text { vol. } \%\end{array}$ & $2.2-11 \%$ \\
\hline & water & $\begin{array}{l}\mathrm{Ag} \\
\text { thiolate }\end{array}$ & $\begin{array}{l}\text { sphere, } \\
10-20 \mathrm{~nm}\end{array}$ & 0.001 vol. $\%$ & $3-7 \%$ \\
\hline \multirow{2}{*}{$\begin{array}{l}\text { Murshed et } \\
\text { al. [24] }\end{array}$} & water & $\mathrm{TiO}_{2}$ & sphere, $15 \mathrm{~nm}$ & $1-5$ vol. $\%$ & $18-29.7 \%$ \\
\hline & water & $\mathrm{TiO}_{2}$ & $\begin{array}{l}\text { tube shape } \\
10 \mathrm{~nm} \times 40 \mathrm{~nm}\end{array}$ & $1-5$ vol. $\%$ & $22-32.8 \%$ \\
\hline
\end{tabular}

\section{Nanofluids and heat transfer}

The origin of wide interest in the nanofluids should be looked in their superior properties in comparison to conventional heat transfer fluids [4]. The substances listed in Fig. 2, for instance: metals or non-metals and fluids, could be used as the nanofluid components.

\subsection{Thermal conductivity of nanofluids}

The thermal conductivity is the most important property for utilization of the nanofluids in energy systems. Many research papers are devoted to this subject and a lot of various models and formulas describing and predicting thermal conductivity values of the 
Table 2. Models of nanofluids thermal conductivity

\begin{tabular}{|c|c|}
\hline Source and brief contents & Thermal conductivity model \\
\hline $\begin{array}{l}\text { Maxwell [7] } \\
\text { - gives good results for low particles volume fraction and } \\
\text { relatively large particles size (microscale or above) }\end{array}$ & $\frac{k_{\text {eff }}}{k_{\mathrm{f}}}=\frac{k_{\mathrm{s}}+2 k_{\mathrm{f}}+2 \phi\left(k_{\mathrm{f}}-k_{\mathrm{p}}\right)}{k_{\mathrm{s}}+2 k_{\mathrm{f}}-\phi\left(k_{\mathrm{f}}-k_{\mathrm{p}}\right)}$ \\
\hline $\begin{array}{l}\text { Yu and Choi [8] } \\
\text { - include the effect of a nanolayer on the particle surface } \\
\text { - choosing a nanolayer thickness of } 2 \mathrm{~nm} \text { and a nanolayer } \\
\text { conductivity greater than ten times that of the base fluid } \\
\text { leads to excellent agreement with data for the CuO- } \\
\text { ethylene glycol nanofluids }\end{array}$ & $\frac{k_{\mathrm{eff}}}{k_{\mathrm{f}}}=\frac{k_{\mathrm{s}}+2 k_{\mathrm{f}}-2 \phi\left(k_{\mathrm{f}}-k_{\mathrm{s}}\right)(1+\eta)^{3}}{k_{\mathrm{s}}+2 k_{\mathrm{f}}+\phi\left(k_{\mathrm{f}}-k_{\mathrm{s}}\right)(1+\eta)^{3}}$ \\
\hline $\begin{array}{l}\text { Hamilton and Crosser [9] } \\
\text { - takes into account particle shape, for the spherical } \\
\text { particles it reproduces the Maxwell result } \\
\text { - the thermal conductivities were measured for mixtures } \\
\text { of the balsa wood and the aluminium particles of several } \\
\text { shapes in the rubber at selected compositions } \\
\text { - using in equation the empirical shape factor } n \text { depends } \\
\text { on the thermal conductivities of the phases and included } \\
\text { particle shape. }\end{array}$ & $\frac{k_{\text {eff }}}{k_{\mathrm{f}}}=\frac{k_{\mathrm{s}}+(n-1) k_{\mathrm{f}}-(n-1)\left(k_{\mathrm{f}}-k_{\mathrm{s}}\right) \phi}{k_{\mathrm{s}}+(n-1) k_{\mathrm{f}}+\left(k_{\mathrm{f}}-k_{\mathrm{s}}\right) \phi}$ \\
\hline $\begin{array}{l}\text { Timofeeva et al. [32] } \\
- \text { the particles volume fraction varied between } 3.6 \text { and } \\
13 \% \\
\text { - for the particles of spherical shape } \\
\text { - for the nanofluids of alumina in water and ethylene } \\
\text { glycol }\end{array}$ & $\frac{k_{\text {eff }}}{k_{\mathrm{f}}}=(1+3 \phi)$ \\
\hline $\begin{array}{l}\text { Koo and Kleinstreuer [13] } \\
\text { - the effects of particle size, particle volume fraction and } \\
\text { temperature (in Kelvin) dependence as well as properties } \\
\text { of base liquid and particle phase were taken into } \\
\text { consideration by considering randomly moving } \\
\text { nanoparticles in the base fluid } \\
\text { - the interparticle potentials for nanofluids with particles } \\
\text { of } d_{\mathrm{p}}>10 \mathrm{~nm} \text {, and } \phi>1 \% \text {, } \\
\text { - the particles material: } \mathrm{Cu}, \mathrm{Al}_{2} \mathrm{O}_{3}, \mathrm{CuO}, \mathrm{TiO}_{2}\end{array}$ & $k_{\mathrm{eff}}=k_{\mathrm{f}}\left[\frac{k_{\mathrm{s}}+2 k_{\mathrm{f}}-2 \phi\left(k_{\mathrm{f}}-k_{\mathrm{s}}\right)}{k_{\mathrm{s}}+2 k_{\mathrm{f}}-\phi\left(k_{\mathrm{f}}-k_{\mathrm{s}}\right)}\right]+5 \cdot 10^{4} \beta_{\mathrm{f}} \mathrm{q}$ \\
\hline $\begin{array}{l}\text { Patel et al. [14] } \\
\text { - the model was found to be predicting the thermal } \\
\text { conductivity accurately over a wide range of particle sizes } \\
(10-100 \mathrm{~nm}) \text {, particle concentrations }(1-8 \%) \text {, particle } \\
\text { materials (the metal particles as well as the metal oxides), } \\
\text { different base fluids (the water, the ethylene glycol) and } \\
\text { temperature range }\left(20-50^{\circ} \mathrm{C}\right) \text {. } \\
\text { - modeling of the micro-convection is an important } \\
\text { conclusion of this work. }\end{array}$ & $\frac{k_{\text {eff }}}{k_{\mathrm{f}}}=1+\frac{k_{s} d_{\mathrm{f}} \phi}{k_{s} d_{\mathrm{s}}(1-\phi)}\left[1+c \frac{2 k_{\mathrm{B}} T d_{\mathrm{s}}}{\pi \alpha_{\mathrm{f}} \mu_{\mathrm{f}} d_{\mathrm{s}}^{2}}\right]$ \\
\hline
\end{tabular}


Table 2 continued. Models of nanofluids thermal conductivity

\begin{tabular}{|c|c|}
\hline Source and brief contents & Thermal conductivity model \\
\hline $\begin{array}{l}\text { Chon et al. [15] } \\
\text { - mobility of the nanoparticles, which } \\
\text { depends on the temperature, is the } \\
\text { most dominating factor for the } \\
\text { thermal conductivity enhancement of } \\
\text { the nanofluids than any other factors } \\
\text { - reported an experimental correlation } \\
\text { for the thermal conductivity of } \mathrm{Al}_{2} \mathrm{O}_{3} \\
\text { nanofluids as a function of the } \\
\text { nanoparticle size (in range of } 11 \mathrm{~nm} \text { to } \\
150 \mathrm{~nm} \text { diameters) in the range of } \\
\text { temperature from } 20 \text { to } 70^{\circ} \mathrm{C}\end{array}$ & $\frac{k_{\text {eff }}}{k_{\mathrm{f}}}=1+64.7 \phi^{0.7460}\left(\frac{d_{\mathrm{f}}}{d_{\mathrm{s}}}\right)^{0.3690}\left(\frac{k_{\mathrm{f}}}{k}\right)^{0.7476} \operatorname{Pr}^{0.9955} \operatorname{Re}^{1.2321}$ \\
\hline $\begin{array}{l}\text { Wasp [33] } \\
\text { - special case of the Hamilton and } \\
\text { Crosser's model with } \mathrm{n}=3 \\
\text { - based on the effective thermal } \\
\text { conductivity of a two-component } \\
\text { mixture }\end{array}$ & $\frac{k_{\text {eff }}}{k_{\mathrm{f}}}=\frac{k_{\mathrm{s}}+2 k_{\mathrm{f}}+2 \phi\left(k_{\mathrm{f}}-k_{\mathrm{s}}\right)}{k_{\mathrm{s}}+2 k_{\mathrm{f}}-\phi\left(k_{\mathrm{f}}-k_{s}\right)}$ \\
\hline $\begin{array}{l}\text { Mintsa et al. [34] } \\
\text { - the results suggest that a relative } \\
\text { increase in the thermal conductivity is } \\
\text { more important at higher temperatures } \\
\text { as well as with smaller diameter } \\
\text { particles } \\
\text { - utilized particles sizes were } 47 \text { and } \\
36 \mathrm{~nm} \text { for the } \mathrm{Al}_{2} \mathrm{O}_{3} \text { nanofluid and } 29 \\
\mathrm{~nm} \text { for the } \mathrm{CuO} \text { nanofluid with the } \\
\text { particle volume fractions up to } 9 \%\end{array}$ & $\frac{k_{\text {eff }}}{k_{\mathrm{f}}}=1.72 \phi+1.0$ \\
\hline $\begin{array}{l}\text { Jang and Choi [12] } \\
\text { - study led to the conclusion that } \\
\text { Brownian motion of the nanoparticles } \\
\text { at the molecular and nanoscale levels } \\
\text { is a key nanoscale mechanism } \\
\text { governing their thermal behavior } \\
\text { - the model is able to predict a } \\
\text { particle-size and temperature- } \\
\text { dependent conductivity of nanofluids } \\
- \text { predicts that the thermal } \\
\text { conductivity of nanofluids containing } \\
\mathrm{Cu} \text { particles of } 6 \mathrm{~nm} \text { size is } \\
\text { significantly higher than that of } \\
\text { nanofluids containing } 38.4 \mathrm{~nm} \mathrm{Al} \mathrm{O}_{3} \\
\text { particles, by up to nearly a factor of } 2 \\
\text { at only } 1 \text { vol. } \% \text { and at } 325 \mathrm{~K}\end{array}$ & $\frac{k_{\text {eff }}}{k_{\mathrm{f}}}=(1-\phi)+B k_{\mathrm{s}} \phi+18 \cdot 10^{6} \frac{3 d_{\mathrm{f}}}{d_{\text {nano }}} k_{\mathrm{f}} \operatorname{Re}_{d_{\mathrm{s}}}^{2} \operatorname{Pr} \phi$ \\
\hline $\begin{array}{l}\text { Wang et al. [35] } \\
\text { - incorporate the particle clustering } \\
\text { for the non-metallic particles and is } \\
\text { valid for very low volume fractions } \\
\text { (below } 0.5 \% \text { ) }\end{array}$ & $\frac{k_{\text {eff }}}{k_{\mathrm{f}}}=\frac{(3 \phi-1) k_{\mathrm{s}} / k_{\mathrm{f}}+[3(1-\phi)-1]+\sqrt{\Delta_{\mathrm{B}}}}{4}$ \\
\hline $\begin{array}{l}\text { Eastman et al. [11] } \\
\text { - theoretical work based on literature }\end{array}$ & $\frac{k_{\text {eff }}}{k_{\mathrm{f}}}=1+\frac{k_{s} \phi d_{\mathrm{f}}}{k_{\mathrm{f}}(1-\phi) d_{s}}$ \\
\hline
\end{tabular}


nanofluids could be found. The simplest models [7-9] take into consideration the thermal conductivity values of nanofluid components, or/and the particles volume fraction. They have tendency to underpredict of nanofluid thermal conductivity in comparison to measured ones $[10,11]$. The next aspects taken into account were: particles shape [9], boundary solid/liquid (in the form of interaction between fluid layer and particles, e.g. advection and/or highly conductive liquid-layer structure at the liquid/particle interface) $[8,12]$, micro-convection with Brownian motion effects [13-15]. Most of the formulas are empirical with coefficients coming from particular experiments, what limits their general usage. Some of the models are presented in Table 2, but there is no model, which would precisely describe nanofluid thermal conductivity. Nevertheless, it is assumed that the fluid with the nanoparticles has higher thermal conductivity than the base fluid.

\subsection{Performance of the nanofluid heat transfer}

The investigations regarding the heat transfer of nanofluid were often presented as comparison between their results and the base fluid emphasizing enhancement of the process.

Unfortunately, many researchers obtained the different results, for example in the case of natural convection heat transfer. Putra et al. [26] conducted an experiment using $\mathrm{Al}_{2} \mathrm{O}_{3}$-water nanofluid and $\mathrm{CuO}$-water nanofluid in a horizontal tube. The result showed that for both nanofluids the heat transfer was lower than for base fluid alone. The numerical analyses performed by Mahmoudi et al. [27] and Khanafer et al. [28] gave contradictive results of thermal performance. The numerical [27], theoretical [29], and experimental [30] studies showed existence of the nanoparticles optimum concentration. At this specific concentration, the nanofluid heat transfer was higher than for the base fluid, however higher particles concentration lowered it [31]. Despite of numerous reports regarding the nanofluid thermal characteristics, there is still a need of additional analyses, which may help to unify the results and allows comparison between them (Table 2). In Table 2: $\phi$ is the nanoparticles concentration, $k_{s}, k_{\mathrm{f}}$ are the thermal conductivity values of the solids particles and base fluid, respectively, $\eta$ is the ratio of the nanolayer thickness to the original particle radius $h / r, n$ is the shape factor, $n=3 / \psi$ and $\psi$ is the sphericity which is the ratio of the surface area of a sphere (with the same volume as the given particle) to the surface area of the particle. The sphericity is 1 and 0.5 for the spherical and cylindrical shapes, respectively, $c$ is the constant to be determined experimentally, $\alpha_{\mathrm{f}}$ is the thermal diffusivity of liquid phase, $k_{\mathrm{B}}$ is the Boltzmann constant, $1.3807 \cdot 10^{-23} \mathrm{~J} / \mathrm{K}, d_{\mathrm{s}}$ is the solid particle diameter, $d_{\mathrm{f}}$ is the molecular diameter of base fluid, $\mu_{\mathrm{f}}$ is the fluid viscosity, $T$ is the fluid temperature, $\beta_{\mathrm{f}}$ is the volumetric coefficient of thermal expansion, $\mathrm{c}_{\mathrm{p}}$ is the specific heat, $\rho_{\mathrm{f}}$ is the density. The Reynolds number for particles is defines as: $\operatorname{Re}_{\mathrm{d}_{\text {nano }}}=C_{\mathrm{R} . \mathrm{M} .} d_{s} / v_{\mathrm{f}}$ where $C_{\mathrm{R} . \mathrm{M} .}$ and $v_{\mathrm{f}}$ are the random motion velocity of nanoparticles (their mean speed) and the kinematic viscosity of the base fluid, respectively, $C_{\text {R.M. }}$ can be defined by: $C_{\text {R.M. }}=D_{0} / l_{\mathrm{f}}$ where: $D_{0}$ is the nanoparticle diffusion coefficient: $D_{0}=k_{\mathrm{B}} T / 3 \pi \mu_{\mathrm{f}} d_{\mathrm{s}}, \operatorname{Pr} \equiv \mu_{\mathrm{f}} / \rho_{\mathrm{f}} \alpha_{\mathrm{f}}, \operatorname{Re} \equiv \rho_{\mathrm{f}} V_{\mathrm{Br}} d_{\mathrm{S}} / \mu_{\mathrm{f}}=\rho_{\mathrm{f}} k_{\mathrm{B}} T / 3 \pi \mu_{\mathrm{f}}{ }^{2} l_{\mathrm{f}}$ where $\mu_{\mathrm{f}}=A \cdot 10^{B /(T-C)}$ and $\mathrm{A}, \mathrm{B}$, and $\mathrm{C}$ are constants, given as $2.414 \cdot 10^{-5}, 247.8$, and 140 , for the case of water, $V_{\mathrm{Br}}$ is the Brownian velocity of the nanoparticles defined as follows $V_{\mathrm{Br}} \equiv\left(k_{\mathrm{B}} T / 3 \pi \mu d_{\mathrm{s}} l_{\mathrm{f}}\right) \cdot\left[T / A \cdot 10^{B /(T-C)}\right], l_{\mathrm{f}}$ is the constant of value equal to $0.17 \mathrm{~nm}$ for the mean free path is used for the water, could be also calculated accordingly: $l_{\mathrm{f}}=1 / \sqrt{2} m \cdot \pi d_{\mathrm{f}}^{2}$ where $m$ represents the molecular number density, $B$ is a constant related to the Kapitza resistance. 
Table 3. The results of solar collectors various studies

\begin{tabular}{|c|c|c|c|c|c|}
\hline Source & Nanofluid & $\begin{array}{l}\text { Particles } \\
\text { size }\end{array}$ & $\begin{array}{l}\text { Particles } \\
\text { volume } \\
\text { fraction }\end{array}$ & $\begin{array}{l}\text { Solar } \\
\text { collector }\end{array}$ & $\begin{array}{l}\text { Results }- \\
\text { improved }\end{array}$ \\
\hline $\begin{array}{l}\text { Yousefi et } \\
\text { al. [47] }\end{array}$ & $\mathrm{Al}_{2} \mathrm{O}_{3} /$ water & $15 \mathrm{~nm}$ & $0.2 \%$ & Flat-plate & up to $28.3 \%$ \\
\hline Kim et al. & $\mathrm{Al}_{2} \mathrm{O}_{3} /$ water & $10: 100 \mathrm{~nm}$ & $0 \%-1.5 \%$ & Flat-plate & $\begin{array}{l}\text { The nanofluid thermal } \\
\text { conductivity was } \\
\text { increased with increase in } \\
\text { the particle concentration, } \\
\text { it decreased with decrease } \\
\text { in particle size. } \\
24.1 \%\end{array}$ \\
\hline $\begin{array}{l}\text { He et al. } \\
\text { [49] }\end{array}$ & $\mathrm{Cu} /$ water & $25 \mathrm{~nm}$ & $0.1 \%$ & Flat-plate & $\begin{array}{l}\text { The efficiency increased } \\
\text { about } 23.83 \%\end{array}$ \\
\hline $\begin{array}{l}\text { Tong et al. } \\
{[50]}\end{array}$ & $\begin{array}{l}\text { multi- } \\
\text { walled } \\
\text { carbon } \\
\text { nanotube/ } \\
\text { water }\end{array}$ & unknown & $0 \%-1 \%$ & $\begin{array}{l}\text { Evacuated } \\
\text { Tube }\end{array}$ & $\begin{array}{l}\text { The efficiency increased } \\
\text { about } 4 \%\end{array}$ \\
\hline $\begin{array}{l}\text { Liu et al. } \\
{[39,40]}\end{array}$ & $\mathrm{CuO} /$ water & $20 \mathrm{~nm}$ & $0.8 \%-1.5 \%$ & $\begin{array}{l}\text { Evacuated } \\
\text { Tube } \\
\text { integrated } \\
\text { with a } \\
\text { compound } \\
\text { parabolic } \\
\text { concentrat } \\
\text { or } \\
\end{array}$ & $\begin{array}{l}\text { max. } 12.4 \% \text { at a mass } \\
\text { concentration of } 1.2 \%\end{array}$ \\
\hline $\begin{array}{l}\text { Goudarzi } \\
\text { et al. [41] }\end{array}$ & $\mathrm{CuO} /$ water & $40 \mathrm{~nm}$ & $\begin{array}{l}0.1 \%, 0.2 \% \\
\text { and } 0.4 \%\end{array}$ & $\begin{array}{c}\text { Cylindrica } \\
1\end{array}$ & $\begin{array}{l}\text { up to } 25 \% \text { at a mass } \\
\text { concentration of } 0.1 \%\end{array}$ \\
\hline $\begin{array}{l}\text { Kasaeian } \\
\text { et al. [51] }\end{array}$ & $\begin{array}{l}\text { carbon } \\
\text { nanotube/oil }\end{array}$ & unknown & $\begin{array}{ll}0.2 \% & \text { and } \\
0.3 \% & \end{array}$ & Parabolic & $\begin{array}{l}4-5 \% \text { and } 5-7 \%, \\
\text { respectively }\end{array}$ \\
\hline $\begin{array}{l}\text { Rahman et } \\
\text { al. [52] }\end{array}$ & $\begin{array}{l}\mathrm{Cu} / \text { water, } \\
\mathrm{Al}_{2} \mathrm{O}_{3} / \text { water, } \\
\mathrm{TiO}_{2} / \text { water }\end{array}$ & unknown & $\begin{array}{l}0 \%, 0.05 \%, \\
0.08 \%, \\
\text { and } 0.1 \%\end{array}$ & Triangular & $\begin{array}{l}\text { the highest improvement } \\
\text { was obtained for } \mathrm{Cu}- \\
\text { water nanofluid }\end{array}$ \\
\hline
\end{tabular}

\section{Nanofluids in solar systems}

One of the novel strategies to improve the solar energy systems efficiency is to use working fluid with better thermo-physical properties such as the nanofluid. The nanofluids in the solar collectors, photovoltaic/thermal systems, solar thermoelectric devices, solar water heaters, solar-geothermal combined cooling heating and power system, evaporative cooling for greenhouses or water desalination have great potential [36-38]. Studies of the nanofluid usage in the solar collectors take into consideration factors like shape of the collector or the nanoparticles material. However the analyses of working nanofluid do not take into consideration the nanoparticles types, shapes or their size. There are a lot of results which cannot be compared and overall conclusion could not be stated. Some of the results revealed that efficiency increased with increasing particles concentration up to an optimal value [3941], however this value can depend on the particles type, their size or shape and moreover, on collector type. Investigation results of various solar collectors types are shown in Table 3. 


\section{Nanofluids in nuclear reactors}

The nanofluids, designed to be used in the nuclear reactor system have to fullfil high safety requirements such as: minimal impact of the nanoparticles on the core neutronic behavior, minimal activation of the nanoparticles by neutron rate, avoidance of excessive coolant radioactivity during steady-state and refuelling operation, compatibility of the nanoparticles with the reactor's chemical and radiation environment and also no erosion effect of the reactor piping and vessel by the nanoparticles [31, 42, 43]. The studies proposed the safest nanoparticles materials: metallic substances that have low neutron absorption cross section - $\mathrm{Al}, \mathrm{Mg}, \mathrm{Zr}, \mathrm{Si}, \mathrm{Bi}$ [44] and $\mathrm{Al}_{2} \mathrm{O}, \mathrm{SiO}_{2}, \mathrm{TiO}_{2}, \mathrm{AlO}_{3}, \mathrm{CeO}_{2}$ or $\mathrm{CuO}[45,46]$.

The thermal characteristics of nanofluids should be investigated with particular care taken about their boiling heat transfer behaviour. It was shown [42] that the nanoparticles could enhance the critical heat flux limit and accelerate the quenching heat transfer. These findings could be utilized in the water-cooled nuclear reactors to realize sizable power uprates in the core, thus attaining significant economic benefits or improving safety margins.

\section{Nanofluids in space application}

The effect of nanofluids utilization in a spacecraft active thermal control system was assessed from a system perspective [53]. A detailed analysis based on the special thermal system specifications, requirements, and component performance showed that the addition of nanofluids to the internal fluid loop (the whole system consisted of - "internal" and "external" loops, however the results are presented only for the internal one) did not result in the mass or power benefits. Moreover, the addition of nanoparticles to the internal fluid loop resulted in increasing mass and energy consumption (higher pumping power). Based on the internal loop results, the conclusion about external loop was formulated by the authors. They stated that the benefits of nanofluid applications would be very small, but they emphasized that it requires verification. The assessment was performed for the aluminum oxide and the copper oxide nanoparticles with concentrations in the range of 0 to $6 \mathrm{vol} \%$. It is possible that for another nanoparticles the results will be more promising. In described studies the magnetic field effect on weakly-magnetic nanofluid components was not taken into consideration.

Also numerical study of ferrofluid (containing nanoparticles in the size of range $5-15 \mathrm{~nm}$ and particles concentration up to $1 \%$ ) under the magnetic field and in space [54] was performed. The influence of such parameters as the Magnetic number, the Hartmann number, the Rayleigh number and the nanoparticle volume fraction on the flow and heat transfer have been investigated. The Magnetic and Hartmann numbers was defined as follows: $\mathrm{Mn}_{\mathrm{f}}=\mu_{0} H_{0}^{2} K^{\prime}\left(T_{h}-T_{c}\right) L^{2} / \mu_{\mathrm{f}} \alpha_{\mathrm{f}}, \mathrm{Ha}=\mu_{0} H_{0} L \sqrt{\sigma_{\mathrm{f}} / \mu_{\mathrm{f}}}$ where $\mu_{0}$ is permeability of vacuum, $H_{0}$ is magnetic field strength, $K^{\prime}$ is a constant value, $\left(T_{\mathrm{h}}-T_{\mathrm{c}}\right)$ is a temperature difference, $L$ is characteristic length scale, $\mu_{\mathrm{f}}$ is dynamic viscosity, $\alpha_{\mathrm{f}}$ is thermal diffusivity and $\sigma_{\mathrm{f}}$ is fluid electrical conductivity. Results show deterioration of heat transfer while the Rayleigh number increased, however the Nusselt number was increasing function of the Magnetic number, the Rayleigh number and the nanoparticle volume fraction while it was decreasing function of the Hartmann number. This studies showed that the flow and heat transfer processes within ferro-nanofluids can be controlled in the space.

\section{Nanofluids in magnetic field - experimental studies}

The magnetic field environment used as a method of the flow and heat transfer control was analyzed numerically, proved experimentally and already reported [55-58]. The first 
experimental studies of strong magnetic field influence on weakly-magnetic (diamagnetic) nanofluids were performed by Authors' [59-61]. The results revealed some ability of magnetic field to change the heat transfer and nanofluid flow behaviour.

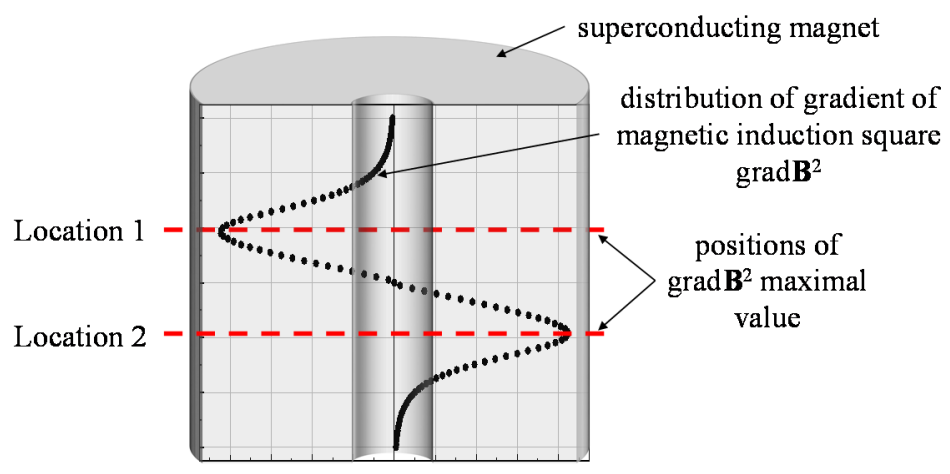

Fig. 3. Distribution of gradient of magnetic induction square with marked location of its two maximal values

(a) Location 1

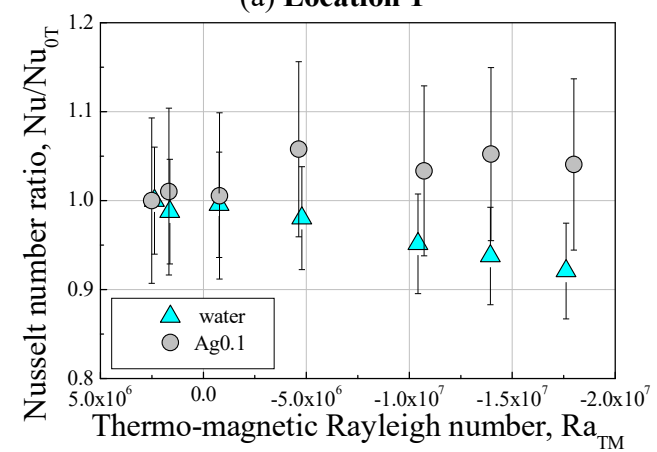

(b) Location 2

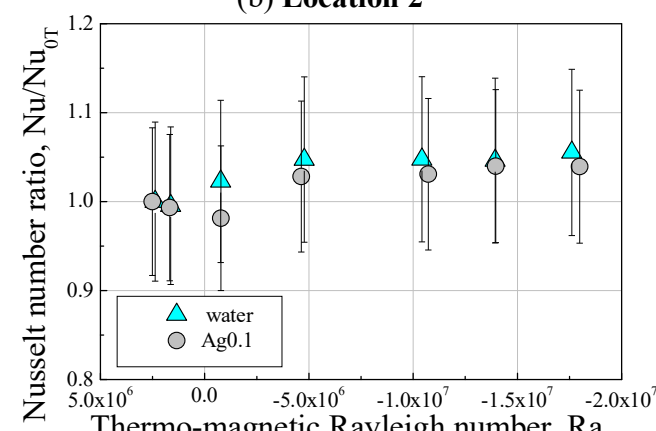

Thermo-magnetic Rayleigh number, $\mathrm{Ra}_{\mathrm{TM}}$

Fig. 4. Heat transfer results in the (a) Location 1 and (b) Location 2

Table 4. Properties of the nanofluid components

\begin{tabular}{|c|c|c|c|c|}
\hline Property & Symbol & Unit & $\begin{array}{c}\text { Water } \\
\text { at } 294 \mathrm{~K}\end{array}$ & Silver \\
\hline Thermal conductivity & $k_{\mathrm{nf}}$ & {$\left[\mathrm{W} \cdot(\mathrm{mK})^{-1}\right]$} & 0.600 & 429 \\
\hline Density & $\rho_{\mathrm{nf}}$ & {$\left[\mathrm{kg} \cdot \mathrm{m}^{-3}\right]$} & 998 & 10500 \\
\hline Specific heat & $c_{\mathrm{p}, \mathrm{nf}}$ & {$\left[\mathrm{J} \cdot(\mathrm{kg} \cdot \mathrm{K})^{-1}\right]$} & 4181 & 235 \\
\hline Thermal expansion coefficient & $\beta_{\mathrm{nf}}$ & {$\left[\mathrm{K}^{-1}\right]$} & $21.37 \cdot 10^{-5}$ & - \\
\hline Dynamic viscosity & $\mu_{\mathrm{nf}}$ & {$\left[\mathrm{kg} \cdot(\mathrm{m} \cdot \mathrm{s})^{-1}\right]$} & $9.84 \cdot 10^{-4}$ & - \\
\hline Mass magnetic susceptibility & $\chi \mathrm{m}$ & {$\left[\mathrm{m}^{3} \cdot \mathrm{kg}^{-1}\right]$} & $-8.86 \cdot 10^{-9}$ & $-2.27 \cdot 10^{-9}$ \\
\hline Volume magnetic susceptibility & $\chi$ & {$[-]$} & $-8.84 \cdot 10^{-6}$ & $-2.38 \cdot 10^{-5}$ \\
\hline
\end{tabular}

The experimental procedure had two main parts: estimation of heat losses in the system and thermo-magnetic convection measurements, as presented in [59]. Magnetic field was generated by superconducting magnet (range of magnetic induction was 0-10 T). Working fluids were both distilled water and silver nanofluid (containing 0.1 vol. $\%$ of particles of 50 - 
$60 \mathrm{~nm}$ size). The properties values of nanofluid components are presented in Table 4. Nanofluid was prepared by two-step method with ultrasonic mixing (with pulse mode).

Square enclosure was filled with analyzed fluid and placed in the magnet working area. There were two tested locations of the enclosure, according to distribution of magnetic induction square gradient (gradB $\left.\mathbf{B}^{2}\right)$, where the maximal value occurred (marked in Fig. 3 as strip lines). In these marked positions the magnetic force has the highest impact on the phenomena present inside the enclosure. Magnetic field influence on the thermal convection in both locations was investigated.

It should be emphasized that the nanofluid components are diamagnetic substances, which means they are slightly repelled from magnetic field. Taking into consideration the magnetic properties of fluids and enclosure locations, the convection attenuation should be observed in the first studied position (Location 1) and its enhancement in the second one (Location 2). The convection reduction or improvement should be illustrated by decreasing or increasing Nusselt number values, respectively.

In this case, the heat transfer results are presented as the Nusselt number ratio (the Nusselt number value is divided by the Nusselt number value at $0 \mathrm{~T}$, without magnetic field influence) dependence on the thermo-magnetic Rayleigh number for both experimental enclosure positions: Location 1 (shown in Fig. 4(a)) and Location 2 (in Fig. 4(b)). The presented data concerns both: diamagnetic single-phase fluid (distilled water) and two-phase fluid (silver nanofluid). The results obtained for water, in both cases (Fig. 4(a) and 4(b)), are as it was expected-Location 1, the convection weakening is observed, while in Location 2 convection strengthening. However for the nanofluid cases (at both enclosure positions) the convection improvement was demonstrated. The study emphasized that the magnetic field has effect on the nanofluid heat transfer performance.

\section{Summary}

In the paper the present and possible nanofluid applications in the energy systems were discussed. The main feature which is attractive for their majority, there is the thermal conductivity. It looks like, the most probable areas of the nanofluid applications are the solar systems due to intensive development of solar techniques.

It should be pointed out, that only few studies concerning nanofluid applications and performance in the space were found and the results are not optimistic. In spite of it, the presented experimental studies showed that strong magnetic field could change the heat transfer performance in comparison to base fluid. This may give another chance to the nanofluids in regard with space application.

Acknowledgment. The present research was supported by the Polish National Science Centre (Project No. 2016/21/N/ST8/01319)

\section{References}

1. J.A. Eastman, S.U.S. Choi, S. Li, L.J. Thompson, Appl Phys Lett 78, 718 (2001)

2. C.H. Chon, K.D. Kihm, J Heat Transfer 127, 810 (2005)

3. K.H. Solangi, S.N. Kazi, MR Luhur, et al, Energy 89, 1065-1086 (2015)

4. S.U.S. Choi, J.A. Eastman, ASME Int Mech Eng Congr Expo (1995)

5. R.V. Pinto, F. Fiorelli, Appl Therm Eng 108, 720-739 (2016)

6. P.K. Das, J Mol Liq 240, 420-446 (2017)

7. J.C. Maxwell A treatise on electricity and magnetism (Dover Publications, Inc., New York, 1954)

8. W. Yu, S.U.S. Choi, J Nanoparticle Res 5, 167-171 (2003)

9. R.L. Hamilton, O.K. Crosser, Ind Eng Chem Fundam 1, 187-191 (1962) 
10. T.G. Myers, M.M. MacDevette, H. Ribera, J Nanoparticle Res 15, 1775 (2013)

11. J.A. Eastman, S.R. Phillpot, S.U.S. Choi, P. Keblinski, Annu Rev Mater Res 34, 219-246 (2004)

12. S.P. Jang, S.U.S. Choi, Appl Phys Lett 84, 4316 (2004)

13. J. Koo, C. Kleinstreuer, J Nanoparticle Res 6, 577-588 (2005)

14. H.E. Patel, T. Sundararajan, T. Pradeep, A. Dasgupta, N. Dasgupta S.K. DAS, Pramana-J Phys 65, 863-869 (2005)

15. C.H. Chon, K.D. Kihm, S.P. Lee, S.U.S. Choi, Appl Phys Lett 87, 153107 (2005)

16. S.K. Das, S.U.S. Choi, W Yu, T Pradeep, Nanofluids, Science and Technology (2007)

17. H. Xie, J. Wang, T. Xi, Y. Liu, Int J Thermophys 23, 571-580 (2002)

18. Y. Xuan, Q. Li, Int J Heat Fluid Fl 21, 58-64 (2000)

19. S.K. Das, N. Putra, P. Thiesen, W. Roetzel, J Heat Transfer 125, 567-574 (2003)

20. J.S. Pang, H.Y. Zhang, L.P. Li, Adv Mater Res 284, 801-805 (2011)

21. J. Garg, B. Poudel, M. Chiesa, J. B. Gordon, J. J. Ma, J. B. Wang, Z. F. Ren, Y. T. Kang, H. Ohtani, J. Nanda, G. H. McKinley, G. Chen, J Appl Phys 103, 074301 (2008)

22. H. Chen, W. Yang, Y. He, Y. Ding, L. Zhang, C. Tan, A.A. Lapkin, D.V. Bavykin, Powder Technol 183, 63-72 (2008)

23. H.E. Patel, S.K. Das, T. Sundararajan, A.S. Nair, B. George, T. Pradeep, Appl Phys Lett 83, $2931-$ $2933(2003)$

24. S.M.S. Murshed, K.C. Leong, C. Yang, Int J Therm Sci 44, 367-373 (2005)

25. D.R. Lide, CRC Handbook of Chemistry and Physics (2003)

26. N. Putra, W. Roetzel, S.K. Das Heat Mass Transf 39, 775-784 (2003)

27. A.H. Mahmoudi, M. Shahi, A.H. Raouf, A. Ghasemian, Int Commun Heat Mass Transf 37, 1135$1141(2010)$

28. K. Khanafer, K. Vafai, M. Lightstone, Int J Heat Mass Transf 46, 3639-3653 (2003)

29. M. Corcione, Int J Therm Sci 49, 1536-1546 (2010)

30. C.J. Ho, W.K. Liu, Y.S. Chang, C.C. Lin, Int J Therm Sci 49, 1345-1353 (2010)

31. D.H. Sukarno, J Phys Conf Ser 795, 012020 (2017)

32. E. Timofeeva, A. Gavrilov, J. McCloskey, Y. Tolmachev, S. Sprunt, L. Lopatina, J. Selinger, Phys Rev E 76, 061203 (2007)

33. E.J. Wasp, J.P. Kenny, R.L. Gandhi Solid-liquid flow, slurry pipeline transportation (1977)

34. H. Mintsa, G. Roy, C. Nguyen, Proc 5th IASME/WSEAS Int Conf Heat Transf Therm Eng Environ 290-294 (2007)

35. B.X. Wang, L.P. Zhou, X.F. Peng, Int J Heat Mass Transf 46, 2665-2672 (2003)

36. O. Mahian, A. Kianifar, S.A. Kalogirou, I. Pop, S. Wongwises, Int J Heat Mass Transf 57, 582 $594(2013)$

37. T.B. Gorji, A.A. Ranjbar, Renew Sustain Energy Rev 72, 10-32 (2017)

38. A.H. Elsheikh, S.W. Sharshir, M.E. Mostafa, F.A. Essa, M.K.A. Ali, Renew Sustain Energy Rev 82, 3483-3502 (2018)

39. Z.H. Liu, R.L. Hu, L. Lu, F. Zhao, H.S. Xiao, Energy Convers Manag 73, 135-143 (2013)

40. L. Lu, Z.H. Liu, H.S. Xiao, Sol Energy 85, 379-387 (2011)

41. K. Goudarzi, E. Shojaeizadeh, F. Nejati, Appl Therm Eng 73, 1236-1243 (2014)

42. T. Yousefi, F. Veysi, E. Shojaeizadeh, S. Zinadini, Renew Energy 39, 293-298 (2012)

43. H. Kim, J. Kim, H. Cho, Energy 118, 1304-1312 (2017)

44. Q. He, S. Zeng, S. Wang, Appl Therm Eng 88, 165-171 (2015)

45. Y. Tong, J. Kim, H. Cho, Renew Energy 83, 463-473 (2015)

46. A. Kasaeian, S. Daviran, R.D. Azarian, A. Rashidi, Energy Convers Manag 89, 368-375 (2015)

47. M.M. Rahman, S. Mojumder, S. Saha, S. Mekhilef, R. Saidur, Int Commun Heat Mass Transf 50, $117-127(2014)$

48. J. Buongiorno, L. Hu, ASME 2009 Sec Int. Conf. Micro/Nanosc Heat Mass Transf. 3, 517-522 (2009)

49. M.K. Albzeirat, M.I. Hussain, R. Ahmad, Int J of App Eng Res, 13, 5528-5533 (2018)

50. L. Fedele, L. Colla, S. Bobbo, S. Barison, F. Agresti, Nanoscale Res Lett 6, 300 (2011) 
51. M. Raja, R. Vijayan, P. Dineshkumar, M. Venkatesan, Renew Sustain Energy Rev 64, 163-173 (2016)

52. N.A. Bin-Abdun, Z.M. Razlan, A.B. Shahriman, D. Hazry, K. Wan, I. Ibrahim, N.S. Kamarrudin, M.F.H. Rani, AIP Conf. Proc. 020085 (2017)

53. E. Ungar, L. Erickson, AIAA Sp 2011 Conf Expo 0-10. (2011)

54. M. Sheikholeslami, M.M. Rashidi, J Taiwan Inst Chem Eng 56, 6-15 (2015)

55. W.A. Wrobel, E. Fornalik-Wajs, J.S. Szmyd, J Phys Conf Ser 395, 012124 (2012)

56. E. Fornalik-Wajs, P. Filar, J. Wajs, A. Roszko, L. Pleskacz and H. Ozoe, J Phys Conf Ser 530, 012041 (2014)

57. P. Filar, E. Fornalik, T. Tagawa, H. Ozoe, J.S. Szmyd, J Heat Transf 128, 183-191 (2006)

58. L. Pleskacz, E. Fornalik-Wajs, J Phys Conf Ser. 530, 012062 (2014)

59. A. Roszko, E. Fornalik-Wajs, Heat Mass Transf 54, 1-12 (2017)

60. A. Roszko, E. Fornalik-Wajs, J Phys Conf Ser 745, 032154 (2016)

61. A. Roszko, E. Fornalik-Wajs, E3S Web Conf 10, 00111 (2016) 